\title{
Asymmetric intraguild predation of Harmonia axyridis (Pallas, 1773) (Coleoptera: Coccinellidae) on a native Coccinellidae guild
}

\author{
Camila Fediuk de Castro-Guedes ${ }^{1 *}$ (1), Lúcia Massutti de Almeida ${ }^{1}$, \\ Mauricio Osvaldo Moura² \\ ${ }^{1}$ Universidade Federal do Paraná (UFPR), Departamento de Zoologia, Laboratório de Sistemática e Bioecologia de Coleoptera \\ (Insecta). Curitiba, PR, Brasil. \\ ${ }^{2}$ Universidade Federal do Paraná (UFPR), Departamento de Zoologia, Laboratório de Dinâmicas Ecológicas. Curitiba, PR, Brasil.
}

\section{A R T I C L E I N F O}

Article history:

Received 12 July 2019

Accepted 15 October 2019

Available online 17 January 2020

Associate Editor: Gustavo Graciolli

\section{Keywords:}

Aphids

biological control

Cinara atlantica

invasive species

non-target organisms

predator

\begin{abstract}
A B S T R A C T
Harmonia axyridis is an exotic species that can cause serious impacts on native biodiversity in areas where it is introduced to act as a biological control agent. This predator is often involved with intraguild predation, in most cases with aphids predators. Here, we report the results of experiments designed to understand the outcome of the invasion of $H$. axyridis on native coccinellid aphidophagous guilds using intraguild predation as a theoretical framework. Tests were conducted to determine the interactions between 1 st and 4 th instars larvae and $H$. axyridis adults, with Cycloneda sanguinea, Cycloneda pulchella, Eriopis connexa and Hippodamia convergens larvae, as well as eggs predation rate. Two treatments were used: absence and presence of food, Cinara atlantica. The results showed that 1 st and 4 th instars larvae and $H$. axyridis adults are able to prey on larvae and eggs of four Coccinellidae species analyzed, and also their own eggs, showing that this exotic species is a dominant predator in this guild of aphidophagous coccinellids. Adding to these results, studies are recommended, especially the monitoring of these species in the field in the long run, reporting their abundance and diversity as well as their behavior and impact within aphidophagous guilds, especially in Coccinellidae species.
\end{abstract}

\section{Introduction}

Invasive species enter a novel environment and have to established and spread while interacting with native species in the communities (Simberloff, 2015; DiTomaso et al., 2017). This new scenario implies new trophic interactions and a rearrangement of community structure, that may be facilitated by the life history strategy of the invader (Raak-van den Berg et al., 2017). However, these interactions can be negative, for example, the introduction of non-native species, aiming biological control is considered a major threat to native biodiversity (Van Lenteren et al., 2003; Brown et al., 2015) because destabilizes native prey and predator populations dynamics, especially in agronomic systems (Van Lenteren et al., 2003; Crowder and Snyder, 2010; Brown et al., 2015; Björklund et al., 2016).

A common hypothesis that explains the successful establishment of invasive predators (naïve prey hypothesis, Cox and Lima, 2006) suggests

\footnotetext{
* Corresponding author.

E-mail: camifc@yahoo.com (C.F. Castro-Guedes)
}

that after the introduction, the effect of a non-native predator on prey dynamics will be increased because of the lack of effective anti-predator strategies and of a common evolutionary history (Michel et al., 2016). However, a non-native predator would also interact with competitors and predators (top predators). As predator community dynamics are thought to be based on negative interactions, such as intraguild predation (IGP) (the killing and eating of species that use similar, often limiting, resources and are thus potential competitors - Polis et al. (1989)), non-native predators growth rate would constrained by such interactions promoting coexistence (Polis et al., 1989; Hin et al., 2011; Fonseca et al., 2017). But, when the non-native predator did not suffer a negative effect from a native predator (enemy release hypothesis), either by absence or ineffectiveness of a top predator, or by a competitor it would not be controlled and the structure of this system could be destabilized (Crowder and Snyder, 2010; Björklund et al., 2016; Roy et al., 2016).

Harmonia axyridis (Pallas, 1773) (Coleoptera: Coccinellidae) is a predatory invasive species which cause serious impacts on native 
biodiversity in areas where it was introduced as a biological control agent of aphids. In particular, aphidophagous Coccinellidae suffer heavy negative effects of $H$. axyridis through competition for prey and predation (Pell et al., 2008; Brown et al., 2014; Roy and Brown, 2015; Roy et al., 2016; Raak-van den Berg et al., 2017). This species may displace native species in agricultural habitats in North America (Colunga-Garcia and Gage, 1998; Michaud, 2002; Evans et al., 2011) and in various regions of Europe (Brown et al., 2011; Roy et al., 2012; Roy and Brown, 2015). Also, in Brazil, there was a decrease in Coccinellidae diversity associated with an increase of $H$. axyridis abundance, suggesting a negative effect upon native species through competition and/or intraguild predation (Martins et al., 2009).

Predators of aphids exploit ephemeral but abundant resources. Aphid colonies are considered ephemeral because they hardly last longer than the time it takes the consumers to develop from egg to adult. Many predators feed on these resources when they are abundant and as a consequence there is a high risk of cannibalism and intraguild predation (Hemptinne et al., 2012; Hemptinne and Magro, 2015). The hypothesis that native coccinelids decline in neotropics through competition or predation (Martins et al., 2009) has been used because it has been shown that aphidophagous coccinelids interact through intraguild predation, in most cases with predators of aphids (Pell et al., 2008), but also with parasitoids and entomopathogens (Roy et al., 2008; Kenis et al., 2010; Meisner et al., 2011; Ingels et al., 2015; Castro-Guedes and Almeida, 2016). Laboratory and field studies have suggested that $H$. axyridis may be the top predator inside the guild of aphidophagous coccinellids and, consequently, the driver of the guild diversity reduction (Nault and Kennedy, 2003; Roy et al., 2006; Snyder and Evans, 2006; Pell et al., 2008; Martins et al., 2009; Brown et al., 2011; Rondoni et al., 2012; Brown et al., 2015). However, there is evidence of cannibalism in H. axyridis (Yasuda et al., 2001; Rondoni et al., 2012; Santos et al., 2014) and also that aggressiveness and predation rates could be size-dependent toward older, and larger instars (Yasuda et al., 2001). Both characteristics, size structure and cannibalism, are theoretically mechanisms that leads to coexistence in IGP models (Polis et al., 1989, Rudolf, 2007).

There are some native Coccinellidae species that are part of aphidophagous guild with $H$. axyridis, such as Cycloneda sanguinea (Linnaeus, 1763), Cycloneda pulchella (Klug, 1829), Eriopis connexa (Germar, 1824) and Hippodamia convergens Guérin-Méneville, 1842. All of these species were already observed co-occurring with $H$. axyridis in different areas, but specially in pine trees, feeding on Cinara atlantica (Wilson, 1919) (Martins et al., 2009). These species are considered potential agents of biological control, mainly of aphids. However, some evidence suggests that declining biodiversity among natural enemies usually weakens biological control, and this can usually be attributed to enemies killing, like intraguild predation and its ecological subset, cannibalism (Snyder, 2019).

Thus, given the importance of IGP regarding biological control success, here, we report the results of experiments designed to understand the outcome of the invasion of Harmonia axyridis on native coccinellid aphidophagous guilds using intraguild predation as a theoretical framework. We tested: 1) whether predation was symmetric or asymmetric between guild members; 2) whether predation is age structured; 3 ) Whether the presence of extra food source (aphids) would change predation rate and cannibalism. From field data sampling (Ware and Majerus, 2008; Ware et al., 2008; Martins et al., 2009; Katsanis et al., 2013; Roy et al., 2016; Sloggett, 2017) we hypothesize that $H$. axyridis will show strong asymmetric predation rates, behaving as a top predator in all instars. Also, we expected that cannibalism would not stabilize predation rates unless when interacting with the presence of an extra food source (Rudolf,
2007). We also predicted that the presence of aphids (extra food source) would reduce intraguild predation rate (Lucas et al., 1998; Yasuda et al., 2004; Rudolf, 2007).

\section{Material and Methods}

Our system is composed by an aphid (Cinara atlantica (Wilson, 1919)) and five predators, Harmonia axyridis (Pallas, 1773), Cycloneda sanguinea (Linnaeus, 1763), Cycloneda pulchella (Klug, 1829), Eriopis connexa (Germar, 1824) and Hippodamia convergens Guérin-Méneville, 1842. All species we tested are multivoltine in Brazil and co-occur temporal and spatially. Therefore, it is likely that the abundance and diversity of this guild of aphidophagous predators are influenced by competition or with $H$. axyridis.

\section{Cinara atlantica (Wilson, 1919)}

Aphids were collected in the field, on branches of Pinus taeda Linnaeus and Pinus elliottii Engelm. infested with Cinara atlantica, in Curitiba, PR and taken to the insect rearing laboratory, Zoology Department, Universidade Federal do Paraná. They were kept at $21 \pm 1^{\circ} \mathrm{C}, 70 \pm 10 \%$ relative humidity and 24 -hour photoperiod to be maintain a sufficient amount for the bioassays.

Aphids were taken from pine branches from the field, with the help of a fine brush and transferred to the new seedlings purchased at a commercial nursery. The seedlings were replaced when required to maintain the stock population, later used to feed the coccinellids, using the same transfer technique. Aphids were separated by size: small (1st and 2nd instar nymphs), medium (3rd and 4th instar nymphs) and adult aphids.

\section{Coccinellidae}

The laboratory population was originated from adult individuals of $H$. axyridis, $C$. sanguinea, $C$. pulchella, E. connexa and H. convergens collected in the field, in pine trees located in Curitiba, PR and taken to the laboratory.

Insects were reared in plastic containers of $500 \mathrm{ml}$, in brood chambers (BOD), at $25^{\circ} \mathrm{C} \pm 1^{\circ} \mathrm{C}$, relative humidity (RH) of $70 \% \pm 10 \%$ and photophase of 12 hours. The prey, $C$. atlantica, was provided daily ad libitum for both larvae and adults. Subsequently, the adults were sexed and, after obtaining the egg masses, they were transferred into Petri dishes of $9 \mathrm{~cm}$ diameter. After hatching, the larvae were individualized in Petri dishes lined with filter paper and a moistened cotton swab along with a drop of honey.

After prepupa formation to the emergence of adult, insects were kept under the same conditions, but without food. The exchange and cleaning of the containers were carried every 48 hours and the observations made daily. Third-generation individuals of each species were used for the experiments.

\section{Experimental design}

All experiments were performed under the same controlled conditions described above, and with 30 replicates for each combination and for each treatment. The observations were made under stereomicroscope ZEISS Stemi SV6 and microscope, to better distinguish the larvae. In some predation experiments with first instar larvae the survivor could not be identified during the experiments. In these cases, the larvae were raised individually until adult stage to identification. 
The outcome of the trials between species was observed after 24 hours of the onset of the experiment. The occurrence of intraguild predation was considered as follows: IGP in favor of $H$. axyridis: $H$. axyridis larvae preyed the larva of another species; IGP in favor of another species: $H$. axyridis larvae was preyed by the larva of another species; IGP absent: both larvae remained alive.

Same instar larvae of different species may be quite different regarding to size and weight. For this reason, in the experiments we tried to combine larvae of the same size to avoid any kind of influence.

In the experiments with an extra food source, the amount of supplied aphids was determined according to the food consumption test reported by Santos et al. (2014), who reported an average of prey consumption of 5.9, 12.7, 22.9, 46.0 and 22.3, respectively, for all four instars and adult.

Experiment 1: Predatory activity of Harmonia axyridis $1^{\text {st }}$ instar larvae

The newly hatched $1^{\text {st }}$ instar larvae were fed for a 24 hours period. A 1-day-old $H$. axyridis individual was transferred to a 3-cm diameter Petri dish, and then, was added a 1-day-old individual from other species (one of the four native coccinelids) to the opposite side of the plate.

Two different treatments were used: Treatment 1: a first instar larva of $H$. axyridis and a first instar larva of another species, without prey supply; Treatment 2: a first instar larva of $H$. axyridis and a first instar larva of another species, with 8 small aphids ( $1^{\text {st }}$ and $2^{\text {nd }}$ nymphs instars).

Experiment 2: Predatory activity of Harmonia axyridis $4^{\text {th }}$ instar larvae

The $4^{\text {th }}$ instar larvae were combined according to the date of the third ecdysis. The larvae were fed for a day and kept without food for twelve hours, until the start of bioassays. A $4^{\text {th }}$ instar larva of $H$. axyridis was transferred to a 9-cm diameter Petri dish and on the opposite side of the plate a $4^{\text {th }}$ instar larvae of another species was added.

Two different treatments were used: Treatment 1: $a 4^{\text {th }}$ instar larva of $H$. axyridis and a $4^{\text {th }}$ instar larva of another species, without prey supply; Treatment 2: a $4^{\text {th }}$ instar larva of $H$. axyridis and a $4^{\text {th }}$ instar larva of another species, with 50 medium aphids ( $3^{\text {rd }}$ and $4^{\text {th }}$ nymphs instars).

Experiment 3: Predatory activity of Harmonia axyridis adult

A seven-days-old adult of $H$. axyridis was randomly chosen from stock population and transferred to a $9 \mathrm{~cm}$ Petri dish and combined with $4^{\text {th }}$ instar larvae of another species. Two different treatments were used: Treatment 1: an adult of $H$. axyridis and a $4^{\text {th }}$ instar larva of another species, without prey supply; Treatment 2: an adult of $H$. axyridis and a $4^{\text {th }}$ instar larva of another species, with 40 adult aphids.
Experiment 4: Egg predation by Harmonia axyridis

In this bioassay, the egg masses of all four species mentioned have been combined with $H$. axyridis, including its own. Masses containing twenty 1-day-old eggs of prey species were placed in $9 \mathrm{~cm}$ diameter Petri dishes, along with a $4^{\text {th }}$ instar larva of $H$. axyridis fed for one day and kept without food for twelve hours, randomly chosen from stock population.

After 24 hours, the number of eggs remaining on the plate was counted, and it was considered preyed only those were completely consumed.

The same experiment was performed with seven-days-old adult H. axyridis, fed for one day and kept without food for twelve hours, randomly chosen from the stock population.

In this experiment, four different treatments were used: Treatment 1: a $4^{\text {th }}$ instar larva of $H$. axyridis and 20 eggs of only one Coccinellidae species, without prey supply; Treatment 2: a $4^{\text {th }}$ instar larva of $H$. axyridis and 20 eggs of only one Coccinellidae species, with 50 aphids; Treatment 3: an adult of $H$. axyridis and 20 eggs of only one Coccinellidae species, without prey supply; Treatment 4: an adult of $H$. axyridis and 20 eggs of only one Coccinellidae species, with 40 aphids.

\section{Statistical analysis}

To test what is the direction of intraguild predation we use to each pair of species a chi-square test. To test the effect of an extra food source on IGP we adjusted, to each species pair tested, a generalized linear model (GLM) with a Quasibinomial distribution to model the overdispersion. To test the occurrence of eggs predation by $H$. axyridis and the effect of an extra food source we adjusted a generalized linear model (GLM) with a QuasiPoisson distribution, to account for overdispersion. All statistical analysis were performed with R 2.1.2 environment ( $R$ Development Core Team, 2011) with libraries MASS (Venables and Ripley, 2002), effects (Fox, 2003) and vegan (Oksanen et al., 2013).

\section{Results}

We detected in all experiments an asymmetric intraguild predation in favor of $H$. axyridis that was independent of the age, except for adults (Table 1). The absence and presence of another food source played a role only when $H$. axyridis were tested together with $C$. sanguinea ( $4^{\text {th }}$ instar larvae experiments), in which the predation in the absence of food was $17 \%$ significantly higher (Table 1 ). In all other trials, predation by $H$ axyrids was not reduced (Table 1 ). In all experiments, two hours

Table 1

Values of the intraguild predation analysis between Harmonia axyridis (Pallas) and Cycloneda sanguinea (L.), Cycloneda pulchella (Klug), Eriopis connexa (Germar) and Hippodamia convergens Guérin-Meneville, in absence and presence of the food Cinara atlantica (Wilson), where $\mathrm{df}=\mathrm{degrees}$ of freedom, $\mathrm{L} 1=1^{\circ}$ instar; $\mathrm{L} 4=4^{\circ} \mathrm{instar}$.

\begin{tabular}{|c|c|c|c|c|c|c|c|}
\hline \multirow{2}{*}{$\begin{array}{l}\text { Development } \\
\text { period }\end{array}$} & \multirow{2}{*}{ Specie } & \multicolumn{3}{|c|}{ Extra food source } & \multicolumn{3}{|c|}{ Predation } \\
\hline & & df & Deviance & $\mathrm{P}$ & $\chi^{2}$ & df & P-value \\
\hline \multirow[t]{4}{*}{ L1 } & C. pulchella & 1.58 & 0.48 & 0.48 & 26.66 & 1 & $<0.001$ \\
\hline & C. sanguinea & 1.58 & 0.08 & 0.76 & 15 & 1 & $<0.001$ \\
\hline & E. connexa & 1.58 & 0.22 & 0.64 & 41.66 & 1 & $<0.0001$ \\
\hline & H. convergens & 1.58 & 0.16 & 0.68 & 35.26 & 1 & $<0.0001$ \\
\hline \multirow[t]{4}{*}{ L4 } & C. pulchella & 1.58 & 0.11 & 0.73 & 24.06 & 1 & $<0.0001$ \\
\hline & C. sanguinea & 1.58 & 7.38 & 0.01 & 41.66 & 1 & $<0.0001$ \\
\hline & E. connexa & 1.58 & 1.77 & 0.18 & 3.26 & 1 & 0.07 \\
\hline & H. convergens & 1.58 & 0.14 & 0.99 & 13.07 & 1 & $<0.0001$ \\
\hline \multirow[t]{4}{*}{ Adult } & C. pulchella & 1.58 & 0.27 & 0.60 & 2.40 & 1 & 0.12 \\
\hline & C. sanguinea & 1.58 & 0 & 1 & 0.26 & 1 & 0.60 \\
\hline & E. connexa & 1.58 & 1.07 & 0.30 & 0.26 & 1 & 0.60 \\
\hline & H. convergens & 1.58 & 0.06 & 0.79 & 0.60 & 1 & 0.43 \\
\hline
\end{tabular}


Table 2

Values of the egg predation of analysis Cycloneda sanguinea(L.), Cycloneda pulchella(Klug), Eriopis connexa (Germar) and Hippodamia convergens Guérin-Meneville, by Harmonia axyridis (Pallas), in the absence and presence of Cinara atlantica (Wilson), where $\mathrm{df}=\mathrm{degrees}$ of freedom and L4=4 ${ }^{\circ}$ instar.

\begin{tabular}{|c|c|c|c|c|}
\hline Development period & Specie & df & Deviance & $\mathrm{P}$ \\
\hline \multirow[t]{5}{*}{ L4 } & C. pulchella & 1.58 & 7.08 & $<0.0001$ \\
\hline & C. sanguinea & 1.58 & 13.93 & $<0.0001$ \\
\hline & E. connexa & 1.58 & 5.74 & $<0.0001$ \\
\hline & H. convergens & 1.58 & 35.34 & $<0.0001$ \\
\hline & H. axyridis & 1.58 & 1.75 & $<0.0001$ \\
\hline \multirow[t]{5}{*}{ Adult } & C. pulchella & 1.58 & 21.52 & $<0.0001$ \\
\hline & C. sanguinea & 1.58 & 17.40 & $<0.0001$ \\
\hline & E. connexa & 1.58 & 52.60 & $<0.0001$ \\
\hline & H. convergens & 1.58 & 33.83 & $<0.0001$ \\
\hline & H. axyridis & 1.58 & 198.66 & $<0.0001$ \\
\hline
\end{tabular}

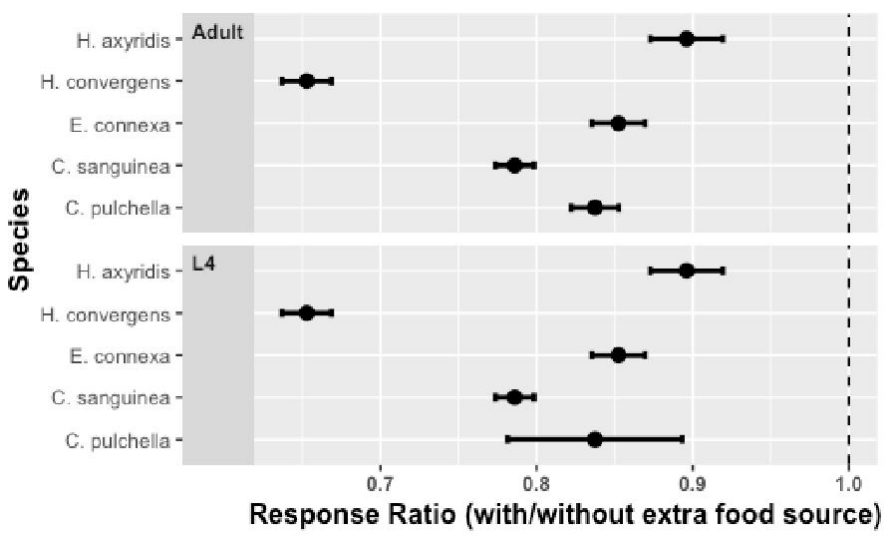

Figure 1 Egg predation response ratio (mean \pm se) estimates of 4 th instar larvae (L4) and adults showing the predation rates difference between groups with and without an extra food source. Values below one mean that predation rates are higher when an extra food source is absent.

after starting the experiment, an average of $30 \%$ of these larvae had already been preyed.

In egg predation experiments, both $4^{\text {th }}$ instar larvae and adults of $H$. axyridis preyed on the eggs of all species, including their own. Cannibalism of $H$. axyrids was significantly influenced by the presence of an extra food source (aphids), with higher predation rates when aphids were not. It occurred, particularly, when $H$. axyridis adults engaged in cannibalism, preying on their own eggs (Figure 1, Table 2).

\section{Discussion}

Our results showed that Harmonia axyridis prey upon all native coccinellids we tested and that this pattern holds independently of immature age or the presence of an extra food source. Also, H. axyridis preyed upon eggs of all Coccinellidae species, including their own, but it seems to prey more on eggs of other species than on their own eggs, independently of the developmental stage (L4 or adult). Cannibalism is lower when there is an extra food source, particularly for adults of $H$. axyridis. Four instar larvae showed a less pronounced tendency. Overal, our predictions hold, cannibalism was lower with an extra food source and $H$. axyridis preyed more on other species eggs than on its own, suggesting a discriminatory capacity, both as L4 or adults.

Harmonia axyridis behaves as a top predator to the aphidophagous coccinellidae guild we tested because it does not suffer predation in laboratoty. This is not occuring only in South America but it is a widespread tendency of $H$. axyridis outcompete and/or prey on other aphidophagous Coccinellidae (Yasuda and Ohnuma, 1999; Yasuda et al.,
2001; Sato et al., 2003; Ware and Majerus, 2008; Pell et al., 2008; Katsanis et al., 2013; Brown et al., 2014; Ingels et al., 2015). So, the key characteristics thought to favor $H$. axyridis in intraguild competition, its larger size, aggressive behavior, extreme polyphagy and the presence of physical and chemical defense strategies, such as the presence of paraescolus throughout its body, benefiting it in confrontation (Félix and Soares, 2004; Pell et al., 2008), are the same that should favors the successful worldwide colonization (Comont et al., 2012). Therefore, the higher predation rate held by $H$. axyridis, independent of stage of development, is related to the greater susceptibility of the other intraguild species, because two hours after starting the experiment, an average of $30 \%$ of these larvae had already been preyed. These results showed that native predators did not have negative impacts on $H$. axyridis which will benefit from an enemy free space, becoming a top predator.

Differences in oviposition behavior influences the probability of larvae of two different predators find themselves in the field. Theoretically, females should select the oviposition site in order to raise immatures survival probabilities (Hodek et al., 2012; Hemptinne and Magro, 2015). Aphidophagous Coccinellidae species generally oviposit near aphid colonies, in order to provide to larval stages enough food for their development (Almohamad et al., 2009; Hodek et al., 2012). Besides it, in the presence of a prey a top predator could decrease intraguild predation (Dixon, 2000; Hodek et al., 2012). If this behavior is adaptative it would decrease fitness of intraguild predators, as our experiment have shown even first instar larvae of $H$. axyridis prey upon all other species of aphidophagous coccinelids. Also, predation rates did not change when prey (aphids) were present at experimental arenas (Ware and Majerus, 2008; Pell et al., 2008, but see Santos et al., 2009). So, any aggregative oviposition behavior of the intraguild members would favor $H$. axyridis. It is noteworthy that, in the field, $H$. axyridis and native species are not necessarily in the same instar when they meet. Therefore, there is the possibility that younger instars of $H$. axyridis become prey of more advanced larval stages of other Coccinellidae species (Katsanis et al., 2013). However, Yasuda et al. (2001) observed that even younger $H$. axyridis larvae may prey more advanced larvae instar of other Coccinellidae species.

The egg predation in Coccinellidae is usually associated with immatures stages (Gagnon et al., 2011; Brown et al., 2015; Roy et al., 2016). As it was expected, our experiment showed that $H$ axyridis fourth instar larvae and adults prey heavily on eggs of intraguild coccinelids tested and that the presence of the prey influenced the predation rates: at low aphid densities, larvae will most likely to carry the IGP and cannibalism (Dixon, 2000; Sato et al., 2003; Yasuda et al., 2004; Cottrell, 2007; Hautier et al., 2011; Smith and Gardiner, 2013). Although cannibalism is widespread in H. axyridis population (Cottrell, 2004; Ware et al., 2008; Katsanis et al., 2013; Santos et al., 2014; this study) we show that $H$ axyridis prey more on heterospecific eggs than 
on conspecific eggs, showing discriminatory behavior. The existence of extrinsic chemicals, present on the surface of the eggs of some species, prevent intraguild predation. This alkaloids concentration can vary within and between species (Hemptinne and Dixon, 2000; Hemptinne et al., 2000; Kajita et al., 2010). In the case of $H$. axyridis eggs, their defensive chemicals have been reported to be essential to explain the resistance of their eggs against intraguild predation by other aphidophagous, which apparently find them unpalatable (Sato and Dixon, 2004; Hemptinne et al., 2012; Martini et al., 2015). More care is required in assessing and describing the likely effects of $H$. axyridis. Our results identified two alternative states predicted by IGP theory (IG top predator and coexistence of IG top predator and IG prey/other predators) in a single system. Harmonia axyridis act as a top predator, and although native Coccinellidae populations, which share the same niche as this predator, may be at risk with the increased of distribution area and establishment of $H$. axyridis. Moreover, it is unlikely that these same Coccinellidae species are preying on H. axyridis. The stability of aphidophagous Coccinellidae IGP systems is increased in the presence of alternative resources and with increasing habitat complexity. So, it is important to consider the influence of intrinsic and extrinsic factors in the extent of IGP. Nevertheless, with the current environmental scenario, the climate changes and the habitat fragmentation may increase the adverse effects of invasive species by reducing refuges for native species, in which they can avoid competition and direct predation from other invaders.

Thus, it is important monitoring these species in the field in the long run, reporting their abundance and diversity as well as their behavior and impact within aphidophagous guilds, especially in Coccinellidae species, that can be used as biological control agents of aphids. In particular, the comparison between coccinellids groups in invaded and not invaded areas will provide better understanding of the impact of this exotic species.

\section{Acknowledgments}

We thank to Conselho Nacional de Desenvolvimento Científico e Tecnológico (CNPq) (CFCG, 401366/2014-6), (LMA, 308992/2017-2) and (MOM, 309154/2014-6) for funding.

\section{Conflicts of interest}

The authors declare no conflicts of interest.

\section{References}

Almohamad, R., Verheggen, F. J., Haubruge, E., 2009. Searching and oviposition behavior of aphidophagous hoverflies (Diptera: Syrphidae): A review. Biotechnol. Agron. Soc. Environ. 13, 467-481. Björklund, H., Santangeli, A., Blanchet, F. G., Huitu, O., Lehtoranta, H., Lindén, H., Valkama, J., Laaksonen, T., 2016. Intraguild predation and competition impacts on a subordinate predator. Oecologia 181, 257-269.

Brown, P. M. J., Thomas, C. E., Lombaert, E., Jeffries, D. L., Estoup, A., Handley, L.-J. L., 2011. The global spread of Harmonia axyridis (Coleoptera: Coccinellidae): distribution, dispersal \& routes of invasion. BioControl 56, 623-641.

Brown, P. M. J., Ingels, B., Wheatley, A., Rhule, E. L., De Clercq, P., Leeuwen, V. T., Thomas, A., 2014. Intraguild predation by Harmonia axyridis (Coleoptera: Coccinellidae) on native insects in Europe: molecular detection from field samples. Entomol. Sci. 18 (1), 1-4.
Brown, P. M. J., Ingels, B., Wheatley, A., 2015. Intraguild predation by Harmonia axyridis (Coleoptera: Coccinellidae) on native insects in Europe: molecular detection from field samples. Entomol. Sci. 18, 130-133.

Castro-Guedes, C. F., Almeida, L. M., 2016. Laboratory investigations reveal that Harmonia axyridis (Coleoptera: Coccinellidae) is a poor host for Dinocampus coccinellae (Hymenoptera: Braconidae) in Brazil. J. Insect Sci. 16, 1-9.

Colunga-Garcia, G. M., Gage, S. H., 1998. Arrival, establishment, and habitat use of the multicolored Asian lady beetle (Coleoptera: Coccinellidae) in a Michigan landscape. Environ. Entomol. 27, 1574-1580.

Comont, R. F., Roy, H. E., Lew, O. T., Harrington, R., Shortall, C. R., Purse, B. V., 2012. Using biological traits to explain ladybird distribution patterns. J. Biogeogr. 39, 1772-1781.

Cottrell, T. E. 2004. Suitability of exotic and native lady beetle eggs (Coleoptera: Coccinellidae) for development of lady beetle larvae. BioControl 31, 362-371.

Cottrell, T. E. 2007. Predation by adult and larval lady beetles (Coleoptera: Coccinellidae) on initial contact with lady beetles eggs. Environ. Entomol. 36, 390-401.

Cox, J.G., Lima, S.L., 2006. Naiveté and an aquaticterrestrial dichotomy in the effects of introduced predators. Trends Ecol. Evolut. 21, 674-680.

Crowder, W., Snyder, W. E., 2010. Eating their way to the top? Mechanisms underlying the success of invasive insect generalist predators. Biol. Invasions 12, 2857-2876.

DiTomaso, J. M., Van Steenwyk, R. A., Nowierski, R. M., Vollmer, J. L., Lane, E., Chilton, E., Burch, P. L., Cowan, P. E., Zimmerman, K., Dionigi, C. P., 2017. Enhancing the effectiveness of biological control programs of invasive species through a more comprehensive pest management approach. Pest Manag. Sci. 73, 9-13.

Dixon, A. F. G., 2000. Insect Predator-Prey Dynamics: Ladybird Beetles and Biological Control. Cambridge University Press, Cambridge.

Evans, E. W., Soares, A. O., Yasuda, H., 2011. Invasions by ladybugs, ladybirds, and other predatory beetles. BioControl 56, 597-611.

Félix, S., Soares, A. O., 2004. Intraguild predation between the aphidophagous ladybird beetles Harmonia axyridis and Coccinella undecimpunctata (Coleoptera: Coccinellidae): The role of body weight. Eur. J. Entomol. 101, 237-242.

Fonseca, M. M., Montserrat, M., Guzma, C., Torres-Campos, I., Pallini, A., Janssen, A., 2017. How to evaluate the potential occurrence of intraguild predation. Exp. Appl. Acarol. 72, 103-114.

Fox, J. 2003. Effect displays in R for Generalised Linear Models. J. Stat. Softw. 8, 1-27.

Gagnon, A. E., Doyon, J., Heimpel, G., 2011. Prey DNA detection success following digestion by intraguild predators: Influence of prey and predator species. Mol. Ecol. Resour. 11, 1022-1032.

Hautier, L., Martin, G. S., Callier, P., Biseau, J.-C., Grégoire, J.-C., 2011. Alkaloids provide evidence of intraguild predation on native coccinellids by Harmonia axyridis in the field. Biol. Invasions 13, 1805-1814.

Hemptinne, J.-L., Dixon, A. F. G., 2000. Defence, oviposition and sex: Semiochemical parsimony in two species of ladybird beetles (Coleoptera: Coccinellidae)? A short review. Eur. J. Entomol. 97, 443-447.

Hemptinne, J.-L., Lognay, G., Gauthier, C., Dixon, A. F. G., 2000. Role of surfasse chemical signals in egg cannibalism and intraguild predation in ladybirds (Coleoptera: coccinellidae). Chemoecology 10, 123-128.

Hemptinne, J.-L., Magro, A., 2015. Role of larval tracks in reducing competition between aphid predators and the consequences for biological control. Acta Soc. Zool. Bohem. 79, 73-82. 
Hemptinne, J.-L., Magro, A., Saladin, C., Dixon, A. F. G., 2012. Role of intraguild predation in aphidophagous guilds. J. Appl. Entomol. 136, 161-170.

Hin, V., Schellekens, T., Persson, L., Roos, A. M., 2011. Coexistence of predator and prey in intraguild predation systems with ontogenetic niche shifts. Am. Nat. 178, 701-714.

Hodek, I., Van Emden, H. F., Honěk, A., 2012. Ecology of Coccinellidae. Wiley-Blackwell, Chichester.

Ingels, B., Van Hassell, P., Van Leeuwen, T., De Clercq, P., 2015. Feeding history affects intraguild interactions between Harmonia axyridis (Coleoptera: Coccinellidae) and Episyrphus balteatus (Diptera: Syrphidae). PLoS One 10, 1-16.

Kajita, Y., Obrycki, J. J., Sloggett, J. J., Haynes, K. F., 2010. Intraspecific alkaloid variation in ladybird eggs and its effects on con- and heterospecific intraguilda predators. Oecologia 163, 313-322.

Katsanis, A., Babendreier, D., Nentwig, W., Kenis, M., 2013. Intraguild predation between the invasive ladybird Harmonia axyridis and non-target European coccinellid species. BioControl 58, 73-83.

Kenis, M., Adriaens, T., Brown, P., Katsanis, A., van Vlaenderen, J., Eschen, R., Golaz, L., Zindel, R., San Martin y Gomez, G., Babendreier, D., Ware, R., 2010. Impact of Harmonia axyridis on European ladybirds: which species are most at risk? IOBC WPRS Bull. 58, 57-59.

Lucas, É., Coderre, D., Brodeur, J., 1998. Intraguild predation among aphid predators: characterization and influence of extraguild prey density. Ecology 79, 1084-1092.

Martini, X., Garrigues, J.-F., Hemptinne, J.-L., 2015. Egg cannibalism by ladybird larvae is less frequent than expected from the nutritional benefit accrued to cannibals. J. Appl. Entomol. 39, 609-617.

Martins, C. B. C., Almeida, L. M., Zonta-de-Carvalho, R. C., Castro, C. F., Pereira, R. A., 2009. Harmonia axyridis: a threat to Brazilian Coccinellidae? Rev. Bras. Entomol. 53, 663-671.

Meisner, M., Harmon, J. P., Harvey, C. T., Ives, A. R., 2011. Intraguild predation on the parasitoid Aphidius erviby the generalist predator Harmonia axyridis: the threat and its avoidance. Entomol. Exp. Appl. 138, 193-201.

Michaud, J. P. 2002. Invasion of the Florida Citrus ecosystem by Harmonia axyridis (Coleoptera: Coccinellidae) and asymmetric competition with a native species, Cycloneda sanguinea. Environ. Entomol. 31, 827-835.

Michel, V. T., Jiménez-Franco, M. V., Naef-Daenzer, B., Grüebler, M. U., 2016. Intraguild predator drives forest edge avoidance of a mesopredator. Ecosphere 7, 1-12.

Nault, B. A., Kennedy, G. G., 2003. Establishment of multicolored Asian lady beetle in Eastern North Carolina: seasonal abundance and crop exploitation within an agricultural landscape. BioControl 48, 363-378.

Oksanen, J., Blanchet, F. G., Kindt, R., Legendre, P., Minchin, P. R., O’Hara, R. B., Simpson, G. L., Solymos, P., Stevens, M. H. H., Wagner, H., 2013. Vegan: Community Ecology Package. R Package Version 2.0-10. Available in: http://vegan.r-forge.r-project.org/ (accessed 5 March 2019).

Pell, J. K., Baverstock, J., Roy, H. E., Ware, R. L., Majerus, M. E. N., 2008. Intraguild predation involving Harmonia axyridis: a review of current knowledge and future perspectives. BioControl 53, 147-168.

Polis, G. A., Myers, C. A., Holt, R. D., 1989. The ecology and evolution of intraguild predation: potential competitors that eat each other. Annu. Rev. Ecol. Syst. 20, 297-330.

R Development Core Team, 2011. R: A Language and Environment for Statistical Computing. R Foundation for Statistical Computing, Vienna, Austria. Available in: http://www.R-project.org (accessed 6 March 2019).
Raak-van den Berg, C., Hemerik, L., van der Werf, W., de Jong, P. W., van Lenteren, J. C., 2017. Life history of the harlequin ladybird, Harmonia axyridis: a global meta-analysis. BioControl 62, 283-296.

Rondoni, G., Onofri, A., Ricci, C., 2012. Laboratory studies on intraguild predation and cannibalism among coccinellid larvae (Coleoptera: coccinellidae). Eur. J. Entomol. 109, 353-362.

Roy, H. E., Brown, P., Majerus, M. E. N., 2006. Harmonia axyridis: a successful biocontrol agent or an invasive threat? In: Eilenberg, J., Hokkanen, H.M.T. (Eds.), An Ecological and Societal Approach to Biological Control. Dordrecht, Netherlands: Kluwer Academic Publishers, pp. 295-309.

Roy, H. E., Baverstock, J., Ware, R. L., Clark, S. J., Majerus, M. E. N., Baverstock, K. E., Pell, J. K., 2008. Intraguild predation of the aphid pathogenic fungus Pandora neoaphidis by the invasive coccinellid Harmonia axyridis. Ecol. Entomol. 33, 1-8.

Roy, H. E., Adriaens, T., Isaac, N. J. B., Kenis, M., Onkelinx, T., San Martin, G., Brown, P. M. J., Hautier, L., Poland, R. L., Roy, D. B., Comont, R., Eschen, R., Frost, R., Zindel, R., Van Vlaenderen, J., Nedvěd, O., Ravn, H. P., Grégoire, J.-C., De Biseau, J.-C., Maes, D., 2012. Invasive alien predator causes rapid declines of native European ladybirds. Divers. Distrib. 18, 717-725.

Roy, H. E., Brown, P. M. J., 2015. Ten years of invasion: Harmonia axyridis (Pallas) (Coleoptera: Coccinellidae) in Britain. Ecol. Entomol. 40 (4), 336-348.

Roy, H. E., Brown, P. M. J., Adriaens, T., Berkvens, N., Borges, I., ClusellaTrullas, S., Comont, R. F., De Clercq, P., Eschen, R., Estoup, A., Evans, E. W., Facon, B., Gardiner, M. M., Gil, A., Grez, A. A., Guillemaud, T., Haelewaters, D., Herz, A., Honek, A., Howe, A. G., Hui, C., Hutchison, W. D., Kenis, M., Koch, R. L., Kulfan, J., Handley, L. L., Lombaert, E., Loomans, A., Losey, J., Lukashuk, A. O., Maes, D., Magro, A., Murray, K. M., Martin, G. S., Martinkova, Z., Minnaar, I. A., Nedved, O., OrlovaBienkowskaja, M. J., Osawa, N., Rabitsch, W., Ravn, H. P., Rondoni, G., Rorke, S. L., Ryndevich, S. K., Saethre, M. G., Sloggett, J. J., Soares, A. O., Stals, R., Tinsley, M. C., Vandereycken, A., van Wielink, P., Viglášová, S., Zach, P., Zakharov, I. A., Zaviezo, T., Zhao, Z., 2016. The harlequin ladybird, Harmonia axyridis: global perspectives on invasion history and ecology. Biol. Invasions 18, 997-1044.

Rudolf, V. H. W. 2007. The interaction of cannibalism and omnivory: consequences for community dynamics. Ecology 88, 2697-2705.

Santos, A. A., Almeida, L. M., Castro-Guedes, C. F., Penteado, S. C. R., 2014. Life table analysis and consumption capacity for Harmonia axyridis (Coleoptera: Coccinellidae), feeding on Cinara atlantica (Hemiptera: Aphididae). Fla. Entomol. 97, 1702-1709.

Santos, N. R. P., Santos-Cividanes, T. M., Cividanes, F. J., Anjos, A. C. R., Oliveira, L. V. L., 2009. Aspectos Biológicos de Harmonia axyridis alimentada com duas espécies de presas e predação intraguilda com Eriopis connexa. Pesq. Agro. Bras. 44 (6), 554-560.

Sato, S., Dixon, A. F. G., 2004. Effect of intraguild predation on the survival and development of three species of aphidophagous ladybirds: consequences for invasive species. Agric. For. Entomol. 6, 21-24.

Sato, S., Dixon, A. F. G., Hironori, Y., 2003. Effect of emigration on cannibalism and intraguild predation in aphidophagous ladybirds. Ecol. Entomol. 28, 628-633.

Simberloff, D. 2015. Non-native invasive species and novel ecosystems. F1000Prime Rep. 7, 1-7.

Sloggett, J. J. 2017. Harmonia axyridis (Coleoptera: Coccinellidae): Smelling the rat in native ladybird declines. Eur. J. Entomol. 114, 455-461.

Smith, C. A., Gardiner, M. M., 2013. Biodiversity loss following the introduction of exotic competitors: Does intraguild predation explain the decline of native lady beetles? PLoS One 8, 1-10.

Snyder, W. E., Evans, E. W., 2006. Ecological effects of invasive arthropod generalist predators. Annu. Rev. Ecol. Evol. Syst. 37, 95-122. 
Snyder, W. E. 2019. Give predators a complement: conserving natural enemy biodiversity to improve biocontrol. Biol. Control 135, 73-82.

Van Lenteren, J. C., Babendreier, D., Bigler, F., Burgio, G., Hokkanen, H. M. T., Kuske, S., Loomans, A. J. M., Menzler-Hokkanen, I., Van Rijn, P. C. J., Thomas, M. B., Tommasini, M. G., Zeng, Q.-Q., 2003. Environmental risk assessment of exotic natural enemies used in inundative biological control. BioControl 48 (1), 3-38.

Venables, W. N., Ripley, B. D., 2002. Modern Applied Statistics with S. Springer, New York.

Ware, R. L., Evans, N., Malpas, L., Michie, L. J., O'Farrell, K., Majerus, M. E. N., 2008. Intraguild predation of British and Japanese coccinellid eggs by the invasive ladybird Harmonia axyridis. NeoBiota 7, 263-275.
Ware, R. L., Majerus, M. E. N., 2008. Intraguild predation of immature stages of British and Japanese coccinellids by the invasive ladybird Harmonia axyridis. BioControl 53, 169-188.

Yasuda, H., Ohnuma, N., 1999. Effect of cannibalism and predation on the larval performance of two ladybird beetles. Entomol. Exp. Appl. 93, 63-67.

Yasuda, H., Kikuchi, T., Kindlmann, P., Sato, S., 2001. Relationships between attack and escape rates, cannibalism, and intraguild predation in larvae of two predatory ladybirds. J. Insect Behav. 14, 373-284.

Yasuda, H., Evans, E. W., Kajita, Y., Urakawa, K., Takizawa, T., 2004. Asymmetric larval interactions between introduced and indigenous ladybirds in North America. Oecologia 141, 722-731. 